\title{
DIALEKTIKA TRADISI SENI BEDENDANG DI KOTA BENGKULU
}

\author{
Salim B. Pili \\ Fakultas Ushuluddin, Adab dan Dakwah IAIN Bengkulu \\ Jalan Raden Fatah Pagar Dewa Bengkulu \\ salim@gmail.com
}

\begin{abstract}
Dialectics of Bedendang Traditions in the City of Bengkulu. In its implementation, the art of singing includes three types of arts, namely the art of poetry, dance and the art of music. The art of singing also has six stages. The first stage is Berandai Dance, which is performed as an opening dance performed by a pair of dancers accompanied by flutes performed in the yard as a way to allow the drummers to go up on stage. The second stage, Ketapang which contained three types of dances, namely handkerchief / shawl, drum dance and plate dance, where the rhymes began to be recited, which were usually entertaining rhymes, and the rhymes were read by just two lines of songs with songs. The third stage, Rampai-rampai which consists almost entirely of pantu-pantun which is carried out in a friendly and rotating manner accompanied by musical instruments such as violin, tambourine, flute, rabanga and other musical instruments. The fourth stage, Suniug humming. The fifth stage, Talibun which is almost the same as the third stage. In the sixth stage, Dendang died in the stage, where this stage as the closing stage which contained almost the same as the second stage.
\end{abstract}

\section{Keywords: Traditions, Bedendang, Bengkulu}

Abstrak: Dialektika Tradisi Seni Bedendang di Kota Bengkulu. Dalam pelaksanaannya, seni berdendang itu meliputi tiga macam kesenian, yaitu seni syair berpantun, seni tari dan seni musik. Seni berdendang ini juga mempunyai enam tahapan. Tahap pertama, Tari Berandai, yang dilakukan sebagai tari pembuka yang dilakukan oleh sepasang penari diiringi oleh seruling dilakukan dihalaman sebagai cara untuk mempersilahkan para pedendang untuk naik kepanggung. Tahap kedua, Ketapang yang berisi dari tiga macam tarian yaitu tari sapu tangan/selendang, tari gendang dan tari piring, dimana pantun-pantun mulai dibacakan, yang biasanya pantun-pantun yang menghibur, dan pantun itu dibacakan dua baris sampirannya saja dengan lagu. Tahap ketiga, Rampai-rampai yang hampir seluruhnya berisikan pantu-pantun yang dilakukan secara bersahutan dan bergiliran diiringi alat-alat musik biola, rebana, seruling, rabanga dan alat-alat musik lainnya. Tahap keempat, Senandung Suniug. Tahap kelima, Talibun yang hampir sama dengan tahap ketiga. Tahap keenam, Dendang mati dibunung, dimana tahap ini sebagai tahap penutup yang berisikan hampir sama dengan tahap kedua.

Kata Kunci: Tradisi, Berdendang, Bengkulu.

\section{Pendahuluan}

Strategi dakwah yang dilakukan oleh juru dakwah Islam hidup, seperti dakwah Wali Songo di Jawa, sekarang dikenal dengan istilah strategi dakwah kultural "Cultural", yaitu dakwah yang dilakukan dengan mempertimbangkan unsur-unsur budaya lokal yang sudah ada sebelumnya, kemudian mengambil bentuk-bentuk wadah kesenian yang sudah ada dan mengkreasikan isinya dengan nilai-nilai Islam yang relevan dan akomodatif pada masa itu.
Bicara tentang dakwah yang kreatif dan inovatif maka tidak ada salahnya jika membahas kesenian sebagai alternatif lain dalam berdakwah, diantaranya adalah lagu-lagu populer sebagai hiburan atau kesenangan yang digandrungi di seluruh dunia pria, wanita dan tua muda sampai anak-anak. Salah satunya adalah cabang seni musik di mana seni musik sedikit banyak berpengaruh dalam kehidupan manusia, baik itu berpengaruh positif maupun negatif, artinya seni musik bisa membuka mata hati manusia untuk 
melakukan sesuatu hal yang baik, seperti ketika seseorang dalam keadaan sulit, patah semangat dan gelisah, musik dapat menghibur dan membangkitkan semangat. Sebaliknya, musik juga bisa membawa kerusakan seperti musik-musik yang biasa diputar di diskotik, dimana tempat itu adalah tempat yang sering membawa manusia kepada maksiat.

Sejak awal perkembangan Islam, kesenian memiliki peranan penting dalam dakwah islamiah, terutama seni bahasa dan seni suara. Allah menciptakan alQuran dalam bahasa Arab yang Maha Balaghah, yang Maha Seni yang luar biasa uslub dan maknanya sehingga tidak dapat ditulis ditiru oleh manusia.

Syair lagu merupakan karya sastra yang disenangi oleh masyarakat. Hal itu dikarenakan syair lagu mempunyai daya pikat dari segi keindahan bahasa, tema dan susunan kalimat, juga rangkaian musiknya. Unsur seni yang dimiliki oleh sebuah syair lagu akan mampu menggugah jiwa seseorang karena pada dasarnya setiap manusia mempunyai rasa keindahan. Oleh karena itu, unsur seni yang ada pada syair atau alunan lagu, merupakan faktor yang menentukan.

$\begin{array}{ccc}\text { Adapun } & \begin{array}{c}\text { syair-syair } \\ \text { berdendang }\end{array} \\ \text { kesenian } & \text { lebih }\end{array}$ mengetengahkan konsep cinta dan kasih sayang sesama manusia. Sidi Gazalba menyatakan, Islam menyuruh manusia beragama untuk berbuat baik, menghargai kesenian, hidup bermasyarakat dan bertaqwa. Karena Islam merupakan fitrah, dan seni adalah fitrah manusia yang dengan sendirinya seni masuk ke dalam ajaran Ad-Dien. Kebudayaan adalah kehidupan, kehidupan adalah pemberian dari Tuhan. Kesenian adalah cabang kebudayaan, dalam bidang kehidupan. Karena itu, fitrah kesenian juga berasal dari Tuhan.

Melihat perkembangan dakwah Islamiyah, banyak ditemukan cara berdakwah yang menggunakan media syair lagu. Pada dasarnya, media ini merupakan cara yang praktis menghibur hati masyarakat. Begitu juga syair lagu dapat difungsikan sebagai filter bagi masyarakat, yakni dengan memanfaatkan media syair lagu, makalah penyajian informasi-informasi keagamaan dapat disisipkan di dalamnya. Hal ini menjadikan syair lagu mempunyai manfaat yang lebih besar dibandingkan dengan tujuan semula yang hanya merupakan produk dari hasil karya seni seseorang. Oleh karena itu, bagi penyelenggara dakwah pemanfaatan media seperti ini, dapatlah kiranya dijadikan sebagai alat untuk menyampaikan misi-misi dakwah Islamiyah.

Kesenian ini sangatlah digandrungi oleh masyarakat Bengkulu, baik generasi tua maupun generasi muda, hampir disemua kelurahan dalam kota Bengkulu memiliki kesenian berdendang dengan nama dan pengurus masingmasing, juga selalu tampil dalam event pernikahan adat Bengkulu.

Dalam pelaksanaannya, seni berdendang itu meliputi tiga macam kesenian, yaitu seni syair berpantun, seni tari dan seni musik. Seni berdendang ini juga mempunyai enam tahapan. Tahap pertama, Tari Berandai, yang dilakukan sebagai tari pembuka yang dilakukan oleh sepasang penari diiringi oleh seruling dilakukan dihalaman sebagai cara untuk mempersilahkan para pedendang untuk naik kepanggung. Tahap kedua, Ketapang yang berisi dari tiga macam tarian yaitu tari sapu tangan/selendang, tari gendang dan tari piring, dimana pantun-pantun mulai dibacakan, yang biasanya pantunpantun yang menghibur, dan pantun itu dibacakan dua baris sampirannya saja dengan lagu. Tahap ketiga, Rampairampai yang hampir seluruhnya berisikan pantu-pantun yang dilakukan secara bersahutan dan bergiliran diiringi alat-alat musik biola, rebana, seruling, rabanga dan alat-alat musik lainnya. Tahap keempat, Senandung Suniug. Tahap kelima, Talibun 
yang hampir sama dengan tahap ketiga. Tahap keenam, Dendang mati dibunung, dimana tahap ini sebagai tahap penutup yang berisikan hampir sama dengan tahap kedua.

Berawal dari kenyataan tersebut, penulis mengajukan proposal penelitian dengan judul Dialektika Tradisi Seni Berdendang di Kota Bengkulu. Pemilihan lokasi ini dilakukan dengan mempertimbangkan fakta bahwa kelompok tradisi seni berdendang di kota Bengkulu ini sering memenangkan lomba seni berdendang di tingkat provinsi Bengkulu dan sering diutus mewakili provinsi Bengkulu dalam acara-acara atau moment dan event budaya tingkat Nasional.

\section{Pembahasan}

Grup Dendang Serawai beralamat di jalan WR.Supratman RT.08/04 Kelurahan kandang limun kota Bengkulu, merupakan grupkesenian adat serawai yang dikelola secara profesional sebagai media seni dan hiburan. Pendirian Grup Dendang Serawai dimaksudkan sebagai media seni dan hiburan, yang bertujuan:

a. Sebagai media pengembangan potensi budaya lokal dengan ciri heterogenitas etnik, sehingga kearifan lokal dapat terus tumbuh dan berkembang ditengah derasnya pengaruh budaya dan luar.

b. Sebagai media dakwah untuk memberikan pencerahan rohani kepada umat Islam dalam menghadapi era global.

c. Sebagai media hiburan bagi masyarakat Bengkulu dalam memenuhi kebutuhan akan kesenian lokal yang hampir hilang oleh kemajuan ilmu pengetahuan dan teknologi.

"Visi Grup Dendang Serawai adalah menjadikan grup sebagai media seni dan hiburan sertasebagai penyambung silatuhrahmi orang-orang
Serawai yang ada di Bengkulu." Adapun misi Grup Dendang Serawai adalah menampilkan kesenian daerah Serawai yang berisikan hiburan, pesan dan nilai yang mendidik yang mencakup aspek agama, edukasi, sosial, budaya dan seni. Saat penelitian ini dilaksanakan, ketua seni dendang adalah bapak Nihardi, sekretaris Bapak Hasan dan Anggotanya adalah: Tanum, Sairi, Sohan, Hon Asri, Jalo', Ali Akbar, Rapni, Mahani, Bardi, Dani, Sakirim, Guntur, Ramadhan, Sapiin, Mardin, Jum, Medok.

\section{Sejarah dan Perkembangan Grup Dendang Serawai}

Grup Dendang Serawai didirikan oleh Bapak Nihardi dan Rapni tahun 1984, yang semula hanya sebagai penerus tradisi Bedendang antara orang-orang Serawai yang tinggal di Bengkulu, dan pertama kali di tamplikan di Gedung Juang 45 sebagai tradisi yang ingin dilestarikan oleh anggota group yang saat itu sedang melaksanakan pernikahan anaknya.

Dari awal terbentuk hingga sekarang grupDendang Serawai belum pernah mengalami pergantian ketua. Dengan mengusung motto seni, hiburan dan dakwah, grup Dendang Serawai diyakini akan menjadi grup berdendang pilihan penikmat seni dalam hal kebutuhannya terhadap kesenian dan kebudayaan lokal. Di samping sebagai media seni danhiburan, keberadaan grup berdendang ini juga mengambil peran sebagai media dakwah dan silahturahmi. Hal ini dimaksudkan untuk mengupayakan penyeimbangan antara kebutuhan jasmani dan rohani. Selain media hiburan grup Dendang Serawai menyajikan nilai dan pesan yang bermanfaat bagi masyarakat. Pertumbuhan dan perkembangan masyarakat provinsi Bengkulu, saat ini telah mendorong pada perkembangan pertumbuhan media kesenian dan 
hiburan. Kota Bengkulu khususnya, juga tidak terlepas dari berdirinya media hiburan dan kesenian dengan beragam corak dan macam yang sesuai dengan keinginan dan kebutuhan masyarakat. Dengan adanya grup Dendang Serawai di kota Bengkulu ada keinginan besar untuk mengembangkan segenap potensi kearifan lokal dalam rangka mewujudkan masyarakat Kota Bengkulu yang berbudaya dengan ciri khas yang unik dan berbeda.

Keberadaan grup Dendang Serawai tidak hanya sebatas untuk kepentingan kesenian dan hiburan saja, tetapi juga mampu menyatukan silahturahmi antar etnis yang ada di Bengkulu, karena grup Dendang Serawai tidak hanya diperuntukkan bagi masyarakat Serawai saja, tetapi juga pada acara-acara pernikahan dengan asal daerah luar Serawai. Untuk mewujudkan cita-cita tersebut grup berdendang memerlukan manajemen yang baik, yang terdiri dari manajemen latihan dan manajemen SDM. Hal ini tentu membutuhkan anggota yang ahli, beriman dan mau berkerja keras. Selain itu juga anggota dendang yang bergabung sudah paham tentang kesenian berdendang, memiliki skill dan juga berakhlak yang baik dalam sikap, tutur kata dan tingkah laku, baik disaat pertunjukan maupun di luar pertunjukan.

Pelaksanaan penelitian ini dilaksanakan mulai dari13 Agustus sampai dengan 11 September 2016. Sebagaimana telah penulis kemukakan pada bab sebelumnya, yaitu mengenai metodologi, data-data lapangan berkaitam dengan fokus penelitian inipenulis peroleh melalui dengan tahap awal yaitu obesrvasi atau pengamatan langsung ke Grup Dendang Serawaikelurahan Kandanng Limun kota Bengkulu.

Selanjutnya peneliti melakukan wawancara baik bersifat formal maupun nonformal. Dengan mempersiapkan pedoman wawancara tertulis maupun tidak tertulis untuk mendapatkan datadata yang diperlukan dalam penelitian, sampai pada akhirnya responden memberikan jawaban wawancara. Hasil wawancara penulis salin dalam catatan lapangan. Peneliti mendokumentasikan alat-alat yang dimiliki oleh grup Dendang Serawai juga kegiatan pementasan yang dilakukan oleh grup dendang ini.Beberapa orang informan sebagai sumber data penulis wawancara ini berulang kali. Tujuannya selain untuk mengembangkan memperdalam dan memperkaya data juga melakukan cek silang dan cek ulang atas informasi yang diberikan narasumber.

Untuk mengetahui apa saja tentang grup berdendang dan tahapan latihan yang dilakukan grup berdendang, penulis melakukan wawancara langsung dengan beberapa anggota grup Dendang Serawai, yaitu: Nihardi, Rapni, Sohan dan Tanum. Dari jawaban-jawaban mereka berikan penulis melihat beberapa pendapat mereka memiliki kesamaan. Untuk menghindari pengulangan jawaban yang sama agar tidak menjenuhkan, maka peneliti menulis beberapa jawaban saja dari yang mereka berikan.

Kesenian Dendang Serawai merupakan grup dendang yang mengangkat kesenian asli lokal provinsi Bengkulu. Grup ini bervisi menjadikan grup Dendang Serawai sebagai media senidan hiburan serta penyambung tali silaturahmi etnis serawai yang ada di kota Bengkulu. Hal itu dapat dilihat dari setiap pertunjukan yang dilakukan dengan menampilkan kesenian lokal yang berisikan hiburan, pesan dan nilai yang mendidik yang mencakup aspek agama, edukasi, sosial, budaya dan seni. Dalam kesenian dendang ini pun, para anggota/pendendang diwajibkan memakai pakaian yang beraspek Islami. Tidak hanya dalam hal pakaian saja, tetapi setiap tahapan dendang juga selalu mempunyai makna yang tersirat 
didalamnya yang berpedoman kepada syariat dan ajaran Islam.

Hal ini diungkapkan oleh ketua grup Dendang Serawai, bapak Nihardi. Dalam melakukan latihan dendang, saya berusaha menyelipkan pesan-pesan moral, hiburan dan dakwah, walaupun dendang yang saya tampilkan tersebut hanya memainkan Serunai dan rebana dengan pantun berirama saja.Tetapi disetiap pantun yang saya bacakan saya sampaikan pesan-pesan moral dan dakwah. Selain itu juga, saya menggunakan suara yang lembut tapi lugas dan dialekbahasanya harus kedaerahan sesuai dengan tempat dimana sayamenampilkan pertunjukan. Hal ini diungkapkan olehbapak Rapni sebagaiguru grup Dendang Serawai dalam perannya sebagai anggota yang memainkan alat musik kolintang.Hal ini juga diungkapkan olehbapak Sohan sebagai anggota grupDendang Serawai dalam perannya sebagai anggota yang memainkan rebana dan bersyair, dikatakannya bahwa untuk memasukkan nilai-nilai seni dan hiburan juga pelestarian budaya asli Bengkulu, dalam acara berdendang maka saya harus serius berlatih dan mengetahui sasaran dakwah yang dituju.

Dari kedua sumber di atas sebenarnya memiliki kesamaan tujuan, bahwa dalam latihan dan pertunjukan yang mereka tampilkanselalu berusaha menyelipkan nilai seni dan hiburan juga tali silahturahmi. Selain itu juga,menurut pendapat bapak Sohan, dalam memilih melantunkan pantun di kesenian berdendang, diseleksi agar unsur-unsur dakwah dan hiburan tetap ada. Anggota grup Dendang Serawai dalam melantunkan syair dan pantunnya untuk penonton menggunakan bahasa yang sesuai dengan bahasa masyarakat, membahasakan bahasa keseharian. Dengan tutur kata yang sopan, lembut dan mudah dimengerti. Selain itu juga seorang anggota harus menguasai materi atau topik pantun yang disampaikan.

Adapun tahapan latihan grup Dendang Serawai yang dilakukan setiap minggu pertama tiap bulannya, bergiliran dari rumah ke rumah para anggotanya, yaitu:

TAHAPAN LATIHAN BERDENDANG

\begin{tabular}{|l|l|l|}
\hline Tahap & \multicolumn{1}{|c|}{$\begin{array}{c}\text { Syair } \\
\text { Dendang }\end{array}$} & \multicolumn{1}{|c|}{$\begin{array}{c}\text { Tari yang } \\
\text { Dimainkan }\end{array}$} \\
\hline Pertama & Ketapang & $\begin{array}{l}\text { Tari Sapu Tangan, } \\
\text { Tari Lagu Duo, Tari } \\
\text { Guai }\end{array}$ \\
\hline Kedua & Lagu Rampai & $\begin{array}{l}\text { Tari Mak Inang, Tari } \\
\text { Piring, Tari Redok, } \\
\text { Tari Payung }\end{array}$ \\
\hline Ketiga & $\begin{array}{l}\text { Senandung } \\
\text { Gunung }\end{array}$ & $\begin{array}{l}\text { Talibun, Tari Kain } \\
\text { Panjang }\end{array}$ \\
\hline Keempat & $\begin{array}{l}\text { Mati } \\
\text { Dibunuh }\end{array}$ & Tari Rendai \\
\hline
\end{tabular}

TAHAP-TAHAP BERDENDANG

\begin{tabular}{|c|l|}
\hline No. & \multicolumn{1}{|c|}{ Tahapan } \\
\hline 1 & Akad Nikah \\
\hline 2 & Belarak (diiringi serunai) \\
\hline 3 & Mengambil Punjung (Jambar) \\
\hline 4 & Tari Rendai, Tari Pedang \\
\hline 5 & Tari Andun \\
\hline 6 & Berdendang \\
\hline
\end{tabular}

Dari jawaban-jawaban yang mereka berikan penulis melihat bahwa banyak memiliki kesamaan. Untuk menghindari pengulangan jawaban yang sama, maka penulis menulis beberapa jawaban saja dari mereka berikan. Berdendang merupakan suatu kesenian lokal yang berupa musik, pantun dan tari dimana melalui kesenian tersebut kita mendapatkan hiburan, pesan moral dan tempat silahturahmi dan membudayakan kebudayaan lokal asli Bengkulu. Selain itu kesenianberdendang dapat dilihat bersama keluarga pada acara pernikahan, khitanan juga aqiqah.

Wawancara dengan Wita (Mahasiswi UMB) tanggal 19Agustus 2016. Hal ini juga diungkapkan olehTuti yangmerupakan Mahasiswa IAIN Bengkulu. 
merupakan bentuk kesenian lokal kepada massa atau masyarakat yang melalui pendengaran dan penglihatan untuk mendapatkan hiburan, pesan moral dan dakwah. Saya sering melihat pertunjukan Dendang, terutama pada waktu acara pernikahan yang diadakan pada malam hari. Acara pertunjukan yang saya senangi di kesenian berdendang adalah Tari-tarian dan Serunai yang diiringi musik tradisional, karena pertunjukan pada tahap-tahap menyampaikan beragam pesan dan nilai-nilai yang bermakna dan sangat jarang diangkat di berbagai kesenian lainnya. Selain itu, saya senang mendengar syair dari para pendendang yang melantunkannya dengan suara yang lugas dan lembut sehingga sangat menghibur.Kalau saya senang melihat pertunujukan berdendang pada malam hari karena pada waktu malam hari saya dapat melihat pertunjukan lokal yang unikasli dari Bengkulu, sehingga saya bisa mengetahui salah satu kesenian lokal Bengkulu dan saya senang mendengarkan lantunan musik yang dikeluarkan dari berbagai macam alat musik tradisonal asli Bengkulu yang tidak kalah menariknya dari alat musik modern sehingga sangat menghibur. Hal ini juga diungkapkan olehbapak Samsuriseorang PNS yang merupakan masyarakat asli Serawai, dikatakannya bahwa pertunjukan diacara berdendang sangat membantu masyarakat dalam memahami salah satu adat Serawai.

$$
\text { Karena melalui kesenian }
$$

berdendang ini, nilai dakwah yang disampaikan dapat didengar oleh wawancara dengan bapak Agustamiseorang Guru Sekolah Dasartanggal 20 Agustus 2016 juga wawancara dengan bapak Sohan pada saat pertunjukan Dendang saat pernikahan salah satu anak dari anggota grup Dendang Serawai, seluruh lapisan masyarakat, terutama pertunjukan yang bemafaskan budaya dan dakwah Islam. Apalagi acara berdendang yang sering ditampikan oleh grupDendang Serawai semuanya beranggotakan orang-orang yang sangat bagus dalam penyampainnya. Selain itu, materinya sesuai dengan situasi dan kondisi serta budaya masyarakat Bengkulu.

Seni dendang ditampilkan dalam pesta perkawinan, khitanan maupun aqiqah, oleh orang-orang tua laki-laki pada waktu malam hari. Sudah merupakan tradisi bagi masyarakat Bengkulu kalau ada orang tua yang menikahkan anaknya, maka pada malam harinya mereka menampilkan dendang. Seni dendang adalah jenis puisi/pantun yang digunakan dengan iringan rebana, seruling, gendang panjang dan biola. Tidak semua orang Bengkulu pandai berdendang, sebab dendang ini harus dipelajari. Caranya dimasing-masing desa ada kongsi/grup dendang. Kongsi dendang maksudnya rombongan orang yang belajar berdendang. Belajar berdendang ini dilaksanakan pada malam hari. Peserta dendang pada umumnya orang laki-laki, baik yang sudah tua (berkeluarga) maupun yang masih muda/bujangan. Sewaktu latihan diangkat seorang guru. Guru itu tentu saja orang yang dianggap mampu dalam berdendang seperti mampu menari, mampu membunyikan serunai, mampu menggosok biola dan mampu memainkan alat musik lainnya seperti kolintang maupun rebana.

Pelaksanaan latihan dilakukan pada malam hari oleh karena di desa, kelurahan dan tempat lain pada umumnya masyarakat petani,nelayan,buruh bangunan, atau profesi lain yang didominasi oleh pekerjaan yang mereka geluti dilakukan di siang hari. Mereka latihan dendang ini tidak dilaksanakan setiap malam, tergantung hasil kesepakatan anggota dendang. Ada yang dilaksanakan sekali seminggu,dan juga setiap hari jika akan mengadakan pertunjukkan. Lama latihan berkisar 2-3 jam, yaitu dari sore sekitar pukul 16.00 sampai sesudah isya jam 
21.00. Tempat latihan di rumah-rumah anggota dendang dengan sistem bergiliran. Siapa yang mendapat giliran menjadi sepokok rumah pelaksanaan latihan dendang maka dialah yang menanggung konsumsinya pada malam itu, baik itu berupa kue atau makanan ringan dan minuman.

Sarana yang dibutuhkan pada saat berdendang itu adalah rebana, biola, serunai, gendang panjang, kolintang, piring dan sapu tangan. Masing-masing anggota dendang harus memiliki rebana. Rebana ini dibuat sendiri oleh masyarakat, bahannya terbuat dari kulit kambing, batang kelapa, dan rotan. Khusus untuk biola dan serunai ada orang tertentu tukang gosok dan hembusnya. Masyarakat yang ikut latihan dendang itu tidak dipungut bayaran, untuk membayar honor guru. Sebagai imbalan anggota dendang kepada gurunya kalau dahulu, jika sudah turun musim sawah, maka anggota dendang tadi membantu guru dendang mengerjakan sawahnya tanpa diminta/diajak. Keinginan membantu bekerjaitu betul-betul datang dari anggota. Hal ini merupakan suatu kebiasaan dari dahulu. Untuk sekarang hal itu jarang bahkan tidak lagi dilakukan karena untuk latihan, antar sesama anggota saling mengajari satu sama lain ataskeahlian yang dimiliki masing-masing anggota. Sambil latihan ini kalau ada orang yang menyuruh berdendang dirumahnya, kalau ada acara-acara lain selain perkawinan, maka grup berdendang itu akan mengabulkan permintaan orang tersebut. Pelaksanaan dendang, jika ada masyarakat yang akan mengawinkan anaknya, maka sepokok rumah pergi mendatangi ketua grupDendangSerawai yang ada di Kandang Limun. Tujuannya adalah supaya pelaksanaan acara pernikahan nanti akan bertambah semarak dengan adanya pertunjukan berdendang dan sebagai pelestarian budaya asli Bengkulu.
Seni dendang ini mempunyai beberapa tahap. Tahap pertama, Ketapang dengantariSapu Tangan, tari Lagu Duo dan tari Guai.Tahap kedua,Lagu Rampai dengan tari Mak Inang, tari Piring, tari Redok, tari Payung. Tahap ketiga, Senandung Gunung dengan Talibun, tari Kain Panjang, tari Rendai yang diiringi oleh Serunai dan gendang panjang. Tahap keempat, Mati dibunuh.

\section{a. Tahap pertama yaitu Ketapang.}

Pada tahap ini dendang yang disampaikan adalah syair/puisi. Maksudnya adalahdendang itu puisi/syair untuk hiburan para penonton sehingga dapat menarik penonton lebih banyak lagi untuk datang melihat pertunjukkan kesenian dendang tersebut. Pada saat ini peserta dendang yang berminat menyampaikan/melantunkan dendang puisi/syair akan berdendang bersama-sama dan akhirnya dari sekian banyak yang berdendang, hanya sebagian yang jadi sedangkan yang lainnya hanya mendengarkan dendang dan membunyikan rebana dan alat musik lain, demikian seterusnya sampai pada hitungan atau aturan yang berlaku.

Berikut puisi/syair dendang pada saat tahap Ketapangdengan 24 irama. Salah satu contoh pantun ketapang dengan not B dan B.

Lari-lari bukanlah Kijang//Sandar pandan pada rumpunnya

Bernyanyi bukannya riang//Menyendarkan badan pada untungnya

Setelah selesai tahap pertama, jenang menghidangkan makanan ringan dan minuman. Kalau dahulu makan dan minuman yang dihidangkan itu ada urutannya, tapi sekarang tentang makan atau minuman apa yang ada sesuai kemampuan sepokok rumah (tuan rumah). Jenang adalah petugas yang ditunjuk oleh sepokok rumah dalam pesta perkawinan itu untuk menghidangkan makanan dan minuman. Jenang itu orang 
yang pandai berdendang sebab selain menghidangkan makanan ia berfungsi lain yaitu sebagai anggota dendang juga.Selesai minum dan makan kue diteruskan dengan menari tapi sebelum dilanjutkan dengan menari pengantin laki-laki masuk/naik ke pengujung dengan diiringi tiupan serunai. Di samping tempat dendang sudah disediakan pelaminan, tempat pengantin duduk. Pengantin laki-laki didampingi inang pengantin, seorang laki-laki juga. Setelah pengantin duduk, acara seni dendang dilanjutkan dengan tari yaitu Tari Sapu Tangan, Tari Lagu Duo dan Tari Guai.

Tari Sapu Tangan yang dilaksanakan oleh dua orang penari dengan memakai sapu tangan. Caranya, sapu tangan diletakkan ditengah-tengah para anggota dendang, lalu peserta dendang yang ingin menari dapat maju mengambil sapu tangan dan mulai menari. Sebelum menari mereka bersujud terlebih dahulu menghadapKepalaDesa atau perangkat desa yang ada didalam ruangan itu. Sewaktu menari, anggota yang lain tetap dalam ruangan diiringi rebana, gendang panjang, serunai, kolintang dan biola. Tarian sapu tangan ini dilakukan 4-5 pasang atau lebih penari sampai tergantung menurut anggota dendang perlu diteruskan, maka diteruskan tetapi kalau dianggap cukup ya cukup. Setelah tari Sapu Tangan dilanjutkan dengan tariLahu Duo dan tari Guai. Setelah semua tarian pada dendang Ketapang selesai dilakukan, pengantin dipersilahkan meninggalkan penghujung.

\section{b. Tahap kedua Rampai.}

Dalam tahap ini rombongan berdendang kembali membunyikan rebana,biola, dan alat musik lainnya pertanda dendang dimulai lagi. Setelah seorang peserta dendang akan berpantun, disinilah mulai kelihatan beda antara Ketapang dengan Rempai, selain pada syair/puisi, juga beda pada pantun. Telah dijelaskan sebelumnya, pada saat Ketapang, puisi dan tarian hanya sebatas hiburan untuk penonton dan menarik penonton lebih banyak lagi untuk melihat pertunjukan dendang.Sedangkan waktu Rampai dilakukan menyampaikan pesanpesan dan nilai-nilai moral atau nasihat untuk setiap anggota dendang maupun pentonton pertunjukan dendang. Contoh dari pantun Rampai, ialah:

Di belakang ada sebatang pisang//Biji $k u$ tanam kemarau datang

Sungai tak dalam dapat
menenggelamkan//Kiranya Tuan dapat menyiram

Duduk bingung berdiri bingung//Siul bercampur sikurang tangis

Siang dan malam kutampungkan doa//Dari jauh ku tinjau-tinjau

Setelah itu, acara dilanjutkan dengan tari Mak Inang, tari Piring, tari Redok dan tari Payung. Tari piring juga dilakukan perorangan dengan penari 5-7 orang denganmenggunakan piring sebagai propertinya. Tari ini juga dilakukan dengan diiringi musik dari alat musik yang digunakan pada acara dendang tersebut.

Pada saat salah seorang anggota dendang sedang berpantun, peserta lain menyimak isi pantun sambil membunyikan rebana. Dalam berdendang pantun ini dilakukan perorangan dan setelah selesai akan dilanjutkan oleh peserta dendang lainnya lagi. Demikian seterusnya sampai berakhir. Berdendang Rampai ini dilakukan 6-7 orang atau lebih.

\section{c. Tahap ketiga yaitu Senandung Gunung.}

Pada tahap ini harisudah hampir larut malam. Namun peserta berdendang tampaknya makin bersemangat.Semangat itu timbul dengan disaksikan oleh banyaknya orang yang menonton tari ditahap awal dan yang lebih jelas inipantun dalam dendang bertambah mantap. Pelaksanaan dendang pada tahap ketiga sama dengan tahap kedua hanya 
saja berbeda pada lagu (melodi alat musik) pantunnya saja. Pada tahap ketiga ini isi pantun bertambah jelas dan mengarah pada dakwah yang berisi pesan/nilai islami dan melodi dari alat musik juga bertambah semangat (semarak/meriah). Sehingga anggota dendang semakin bersemangat untuk membalas pantun yang ada. Pada tahap ini pantun yang dibawakan juga lebih banyak, ini maksudkan agar pesan yang diterima oleh anggota dan penonton dendang lebih banyak dan nantinya dapat dijadikan nasehat serta diaplikasikan. Pantun pada tahap Senandung Gunung yaitu sebagai berikut:

Di bulan Ramadhan orang tarawih//Sudah sembahyang membaca Qur'an//Orang beriman hidupnya salih//Dadanya lapang lakunya sopan

Di bulan Ramadhan orang tadarus//Membaca Qur'an beramai-ramai

Orang beriman hatinya lurus //Duduk berjalan elok perangai

Di bulan Ramadhan banyak bertobat//Memohonkan ampun kepada Allah Orang beriman hidup bermanfaat//Sembarang kerja membawa faedah

Selesai tahap ini jenang kembali menghidangkan makanan atau minuman. Setelah berisitahat, anggota tim berdendang kembali melanjutkan pertunjukan.Dalam tahap ini juga terdapat pertunjukkan Talibun, tari Kain Panjang dan tari Rendai.

Talibun merupakan pertunjukan berbalas pantun yang dilakukan perorangan, dan akan dilanjutkan/disambut oleh anggota tim lainnya. Pada tahap ini hanya diiringi oleh rebana saja. Sewaktu berbalas pantun petugas/anggota-anggota yang membunyikan rebana namanya tukang redok. Tukang redok maksudnya sebagai musik pengiring saat berbalas pantun.
Pantun yang sering digunakan saat Talibun dilakukanadalah:

Sungguh indah pintu dipahat//Burung puyuh di atas dahan

Kalau hidup hendak selamat//Taat selalu perintah Tuhan

Halia ini tanam-tanaman//Ke barat juga akan rebahnya

Dunia ini pinjam-pinjaman//Ke akhirat juga akan sudahnya

Redup bulan nampak nak hujan//Pasang pelita sampai berjelaga

Hidup mati di tangan Tuhan//Tiada siapa dapat menduga

Tari selanjutnya dalam tahap ini adalah tari Rendai. Tari Rendai dilakukan oleh dua orang (sepasang) yang diiringi oleh tiupan seruling.

\section{d. Tahap keempat yaitu dendang Mati Dibunuh.}

Pada tahap dendang ini berisi puisi/syair hiburan setelah tadi mendengarkan pantun yang bernilaikan dakwah Islami. Tahap ini tidak jauh berbeda dengan tahap kedua, terdapat tarian juga pada tahap ini. Ini dimaksudkan agar para penonton nantinya mau kembali melihat acara pertunjukan berdendang ini.

Awal dari tahap ini dimulai dengan berpuisi/syair. Adapun bunyi syair pada tahap ini yaitu:

Oi.... Oi....

Pecah belah gunung, batulah digunung

Gunung senandung gunung

Oi.... Oi.... Oi....

Pecah belah gunung, batulah digunung

Gunung senandung la gunung malam

Oi.... Oi...Angin malam berjalanlah

Oi.... Gunung senandunglah gunung

Oi.... Oi.... Angin malam berjalanlah malam

Oi... Gunung senandunglah gunung 
Setelah dendang dibacakan dilanjutkan dengan tari yang berurutan sebagai berikut yaitu tari Kecik, tari Mutus Tari Kecik,tari Kain dan tari Mutus Tari Kain. Semua tari itu dilakukan berpasangan kecuali tari Mutus tari Kain yang diiringi oleh alunan bunyi dari alat musik berdendang. Pada tari ini hanya tari Kain dantari Mutus Tari Kain yang menggunakan properti (alat) berupa kain.

Setelah tari Kain dilakukan, pengantin laki-laki diharuskan naik ke penghujung dengan diiringi bunyi serunai dan gendang. Setelah itu pengantin melakukan tarian "Mutus Tari Kain" yang akan/boleh diwakilkan oleh ketua kerja/ketua adat atau yang mewakili. Tarian ini bertanda bahwa acara dendang telah selesai atau semua tahap dari acara berdendang ini telah selesai dilaksanakan.

Selesai tahap dendang tersebut jenang kembali menghidangkan makanan dan minuman untuk anggota tim dendang. Setelah beristirahat, ketua jenang menyampaikan kata sambutan yang isinya ucapan terima kasih dan mohon maaf kepada anggota dendang.

Akhirnya dendang ditutup dengan pembacaan do'a selamat. Anggota dendang pulang dengan membawa bungkusan yang berisi kue dari sepokok rumah sebagai tanda ucapan terimakasih.

\section{Kesimpulan}

Berdasarkan hasil analisis terhadap temuan penelitian yang telah dilakukan dapat peneliti simpulkan, sebagai berikut: pertama, Kesenian bedendang bertujuan tidak hanya sebagai kesenian dan hiburan, tetapi juga sebagai pelestarian kesenian asli provinsi Bengkulu dan salah satu pengerat tali silahturahmi, karena anggota Grup Dendang Serawai tidak hanya terdiri dari etnis Serawai, tetapi juga dari berbagai daerah di Bengkulu. Kedua, Deskripsi syair/pantun dalam kesenian berdendang, pada intinya menggambarkan tentang Habluminan'nas dan Habluminaulah. Ketiga, Pesan nasehat dan dakwah yang terdapat dalam syair/pesan kesenian Dendang Serawai adalah nasehat untuk selalu berbuat baik sebagai manusia dan mematuhi perintah Allah SWT juga menjauhi segala larangannya.

\section{Referensi}

Efwandi. 1999. Kesenian Tradisional Pada Masyarakat Bengkulu. Bengkulu: Selendang Bumi Bengkulu.

Kaplan, David. 2002.Teori Budaya. Yogyakarta: Pustaka Pelajar.

Koentjaningrat. 1996. Pengantar Antropologi. Jakarta: Rineka Cipta. 2009. Pengantar Ilmu Antropologi. Jakarta: Rineka Cipta.

Mandala, Adrian. Keragaman Suku Bangsa dan Budaya Nama-nama suku bangsa di Indonesia, diakses pada tanggal 13 Agustus 2016 dengan alamathttp://www.academia.edu/6207 906/Keragaman_Suku_Bangsa_dan_Bu daya_Nama_nama_suku_bangsa_di_In donesia.

Setiyanto,Agus.2015. Gerakan Sosial Masyarakat Bengkulu Abad XIX.Yogyakarta: Ombak.

Sumber Data Badan Pusat Statistik tahun 2015 tentang Wilayah dan Kependudukan.

Sumber Data Dokumen Grup Dendang Serawai Tahun 2016.

Tim Redaksi Departemen Pendidikan dan Kebudayaan. 2000.Analisis Kebudayaan. Jakarta: Departemen Pendidikan dan Kebudayaan.

Tim Anggota IKAPI. 2013.Peradaban di Pantai Barat Sumatera: Perkembangan Hunian dan Budaya di Wilayah Bengkulu. Palembang: Ombak.

Tim Penyusun Dinas Pariwisata Provinsi Bengkulu. 2004.Bunga Rampai Melayu Bengkulu.Bengkulu: Dinas Pariwisata Provinsi Bengkulu.

Waridah,Siti.1997. Antropologi. Jakarta: Bumi Aksara.

Wawancara dengan Nihardi, Rapni, Sohan, Wita, Tuti, Samsuri, Agustami. Agustus 2016. 